University of Nebraska - Lincoln

DigitalCommons@University of Nebraska - Lincoln

2013

Certified Angus, Certified Patriot: Breeding, Bodies, and Pedigree

Practices

Scout Calvert

Follow this and additional works at: https://digitalcommons.unl.edu/libraryscience

Part of the Beef Science Commons, Genetics and Genomics Commons, and the Library and Information Science Commons

This Article is brought to you for free and open access by the Libraries at University of Nebraska-Lincoln at DigitalCommons@University of Nebraska - Lincoln. It has been accepted for inclusion in Faculty Publications, UNL Libraries by an authorized administrator of DigitalCommons@University of Nebraska - Lincoln. 


\title{
Certified Angus, Certified Patriot: Breeding, Bodies, and Pedigree Practices
}

\author{
Scout Calvert \\ Department of Sociology, Michigan State University, East Lansing, MI, USA \\ Correspondence - Scout Calvert, University of Nebraska-Lincoln Libraries, \\ P.O. Box 4100, Lincoln, NE 68588; email scout.calvert@unl.edu
}

\begin{abstract}
The pedigree chart is a cornerstone technology for producing bodies and value in livestock pure breeding. It organizes a cluster of processes, technologies, and discourses gathered under the rubric "pedigree practices." Angus breeders commonly use artificial insemination to import performance "genetics" into their herds, using the "expected progeny differences" predicted by massive pedigree databases that now also contain phenotype data reported by cattle growers. Discourses of biological inheritance, good breeding, and pedigrees arose in the eighteenth century, concomitant with a fascination with races, species, and other biological kinds. A case study from Angus cattle breeding illustrates pedigree practices and the bodies made through them, showing how information and computing technologies, assisted reproductive technologies, and discourses of good breeding, purity, health, and disease leveraged a single bull and the two genetic diseases he carried into the pedigrees of up to $10 \%$ of the Angus herd. Technologies now widely used in human reproductive medicine were developed for use in livestock animals, especially cattle, extending a long relationship between cows and humans. While the development of these pedigree practices
\end{abstract}

Published in Science as Culture, 22:3 (2013), pp. 291-313.

doi:10.1080/09505431.2012.718755

Copyright (C) 2013 Process Press; published by Routledge/Taylor \& Francis Group. Used by permission.

Published 2 October 2012. 
represents increased control over animal reproduction and bodies, it has also been instrumental in rendering all animal bodies, including human bodies, not only more technically but also more rhetorically available for reproductive interventions. These interventions may amplify anxieties about health, species, breed, and kin while also providing opportunities for contesting the boundaries of these nature-cultural categories.

Keywords: Angus cattle, animal studies, pedigrees, genealogy, genetic disease, assisted reproductive technologies

\section{Introduction}

While doing fieldwork on a small Midwestern farm, a visitor to the farm-a horse breeder-was impressed with a straight couple on the farm who, in their 30s, were childless. Accustomed to making matches, he insisted in a conversation with the woman and myself that she should have babies; that she had good genes; that she was a good genetic match to her partner; and that she had an obligation to society to create children with those genes. The farm hand tried amiably to steer the conversation away, bristling at the undue and persistent attention to her private affairs by a virtual stranger.

Perhaps in another situation, the conversation would have been forbidden altogether, or grown uncomfortable more quickly, but reproduction is a topic close at hand on a farm, and we had in fact been talking about rare livestock breeds. The breeder remarked that it was up to the farm hands to reproduce because "most people are too inbred." This was an astounding claim, demonstrably untrue, but it signaled the fraught entanglements of genealogy and reproduction with discourses of "good breeding" (Smithers, 2009). Tellingly, when the conversation turned to breeding methods for horses, the breeder described a program of very close line breeding, of inbreeding, used to stabilize breeds by producing animals who are homozygous for desirable traits: "I always mate the son back to the mother or the daughter to the father."

This conversation handily brought together crucial concerns for a critical genealogy - not in the Nietzschean or Foucauldian sense, but in the ordinary sense of pedigrees and family history. The story is a clue to the kind of troubling of categories that reproductive matters provoke at the boundaries between kin and kind, human and kine. 
Miscegenation, purity, inbreeding, and hybridity are among the key terms in lay and scientific obsessions with defining breeds, species, and races, that mark the modern era in the American and European context. These matters are embodied in the tools for genealogical practice and livestock breeding.

The primary purpose of this paper is to investigate how discourses, processes, and technologies related to breeding and the construction of families work together, particularly given the development and widespread use of information and computing technologies (ICTs), genetic testing, and assisted reproductive technologies (ARTs). I call these discourses, processes, and technologies "pedigree practices" and trace how they manifest in cattle breeding as a site of practice. What are the interplays between and among pedigree practices and the bodies produced through them? The secondary aim of this paper is to trace the historical entanglements of livestock animal and human genealogies in order to identify the work these pedigree practices might do as they mutate and move between domains. Pedigrees and their auxiliaries did not arise independently and discretely in genealogical practice and livestock breeding. Rather, the practice of keeping animal and human genealogies arose together and with other techniques and discourses. How might this investigation of pedigree practices inform our understanding of animal-human relationships, as well as human reproduction, family history, and genealogy?

I will focus on the world of Angus cattle breeding, where discourses about economic value, purity, and disease are explicit, and pedigree practices clearly shape cattle breeds and bodies. These are inflected in human worlds where discourses of "good breeding" are generally retrospective; still, categories that reflect a preoccupation with race, miscegenation, and purity are still embedded in contemporary genealogical tools, including ICTs and genetic tests, with implications for prospective families. When technologies for managing reproduction move between domains, anxieties about category boundaries, good breeding, and family emerge, as we see in recent news stories about the successes of reproductive technologies in human worlds (Mroz, 2011; Gootman, 2012). However, in contemporary pedigree practices, marked by a confluence of ICTs, ARTs, and genetic technologies, participants are unable to set hard and fast boundaries around categories that had seemed so natural. As I argue, when humans and bovines 
travel together in the reproductive borderlands, reproduction is denaturalized, increasing its availability for technical intervention while amplifying anxieties about kin groups, family relationships, and biological filiation. After a short review of the related literature, I will offer a case study from a recent incident in Angus pure breeding and describe the history of Angus pedigree practices in the USA. As I conclude, I will touch on some points of connection with technologies for human family making that suggest future explorations in human-nonhuman animal relations.

\section{Pure Breeding and Good Breeding}

I situate this project in the overlap between several literatures, bringing concerns about agency in human-animal relationships (Haraway, 2008; Coppin, 2008) to histories of genealogical practice, breed registries, pure breeding, and scientific discourse about biological kinds. Modern human and animal pedigree keeping co-emerged in the Victorian era with the breeding and showing of prize livestock by wealthy elites (Ritvo, 1987), after perhaps a century of debate in English society about whether "civility and virtue"-the qualities of "good breeding" - were hereditary or could be cultivated (Smithers, 2009, p. 15). As Harriet Ritvo argues "the maintenance of high genealogical standards was an issue for the breeders as well as the bred" (1996, p. 45).

Cattle have long been domesticated, and have a prominent place in the history of the industrialization of animal bodies (Clarke, 1998; Orland, 2004). Many people have regular contact with cattle through their consumption of meat and dairy products; human populations that can digest bovine milk protein evolved to do so while living in close quarters with cattle (Beja-Pereira et al., 2003; Tishkoff et al., 2007). But more importantly for my concerns, not only did the recording of cow families co-arise with human genealogy, but also reproductive technologies that are now used mundanely in human reproduction were often developed and tested in cattle (Clarke, 1998).

The first cow catalogue, the Short Horn Herdbook, was modelled on the General Stud Book, a registry of thoroughbred horses, published in 1793 and the first of its kind. As Ritvo (1987, p. 60) argues, "the appearance of the first volume of the General Short-Horned Herd Book in 
1822 emphasized the analogy between human and bovine genealogy." A purebred animal was a reflection of the good breeding and gentility of its owner (p. 5). It therefore "was not surprising that [prize animals] were valued for the qualities that distinguished the human elite: dignity, social position, and breeding" (p. 6o). These "rhetorical animals," as Ritvo calls them, "were uniquely suitable subjects for rhetoric that both celebrated human power and extended its sway, especially because they concealed this theme at the same time that they expressed it" (p. 6).

The publication of two of the most famous human genealogies coincided with the emergence of these livestock records: Debrett's The New Peerage in 1769 and Burke's Peerage and Baronetage in 1826. Ritvo (1987, p. 302, fn 41) refers to these as "human studbooks" and observes that "apparently even established aristocratic and gentry families were wont to maintain their pedigrees with determination and enthusiasm." Other livestock breed registries followed: Hereford in 1846 and Aberdeen Angus in 1862 (Derry, 2003, pp. 6-7). MacDonald and Sinclair's History of Polled Aberdeen or Angus Cattle ("illustrated with animal portraits") was printed in 1882; in 1883, The American Aberdeen-Angus Association was founded. It published its first herdbook in 1885 .

Record keeping signals the beginning of the standardization of livestock animals' bodies, which required a new field of knowledge. Robert Bakewell had already been "improving" livestock breeds in the eighteenth century, but eschewed record keeping (Ritvo, 1987; Derry, 2003). Barbara Orland chronicles the development of consistent data collection processes through the nineteenth century that preceded the standardization of dairy cattle and appeared to contribute to a dramatic increase in milk production (2004). Statistical evaluation became a possibility with the development of new information technologies in the twentieth century (Evans, 2001).

Pedigrees and their auxiliary technologies carry with them the historical baggage of their origins. As Smithers (2009, p. 16) argues, "the legal and social taboos placed on interracial marriage in the early [American] republic meant that the qualities associated with well-bred citizens were reserved strictly for white citizens." In US human genealogical practice, for example, the archival resources used to identify potential ancestors for recording on a pedigree chart are structured 
by racial categories (Lee, 1993), the legacies of Indian removal that produced enrolment lists, legal coverture, which subsumed women's identities under their fathers or husbands, and property ownership, since census, court records, and tax records are the most consistently extant historical records in which the names of ordinary people might be found. Since emerging technologies are built on an "installed base" of familiar, previously adopted infrastructures, conventions, and designs (Bowker and Star, 1999), these historical categories structure both contemporary genealogical practice and the information and reproductive technologies used to engage in them. Emerging technologies used in "pedigree practices" are not limited to electronic versions of pedigree charts, but include assisted reproductive technologies, medical and ancestral genetic tests, and databases of genetic markers and phenotype records. Potent new technologies harness "lively capital" (Derry, 2003; Haraway, 2008) and related discourses to construct families, create new bodies, define national and tribal boundaries, and produce identities.

\section{Pedigree Practices in Two Domains}

The pedigree chart organizes and scaffolds the data needed for the activities of both Angus growers and US family historians, and also for the production of genetic knowledge and commodities. For Angus growers, the pedigree entitles the animals to registration in the Angus herdbook; this increases their value as sires and dams, in part because their offspring will be qualified to be "Certified Angus" (see Figure 1), and to bring a higher price on the beef market. Purebred cattle reflect the prestige of "the breed of noble bloods" back on their owners (Ritvo, 1987; Lingle, 2001). For family historians, a pedigree and documentation showing direct, biological descent is required to certify qualification for admission to hereditary patriotic orders like the Daughters of the American Revolution (DAR), the Mayflower Society, and other lineage societies. A long pedigree in itself is a signifier of prestige in genealogical worlds, and denotes a sense of "good breeding" retrospectively.

Because contemporary pedigree keeping for both humans and livestock co-emerged in the Victorian era (Ritvo, 1987), I consider both 


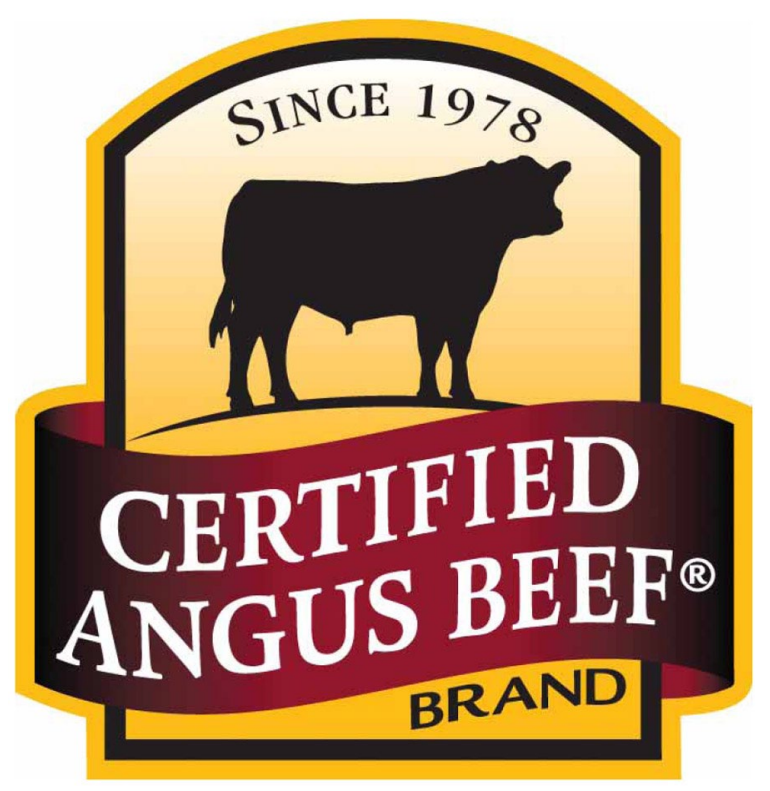

Figure 1. The first of its kind in 1978, the Certified Angus Beef ${ }^{\circledR}$ marketing program made Angus synonymous with succulent, high quality beef. Credit: Certified Angus Beef LLC.

of them together. I develop the rubric of "pedigree practices" to encompass the varied discourses, technologies, and processes and to trace some of their travels between and within human and livestock domains. Haraway's (2008) concept of "natureculture" is useful here as it problematizes the separation between apparent binaries like human and animal, insisting on their inextricability and refusing easy reifications. Pedigree practices themselves are naturecultural, serving not only to record but also to simultaneously produce social relations and biological filiations.

The analytic concept of pedigree practices encompasses the assortment of processes, technologies, and discourses at play in what looks like the straightforward construction of a pedigree chart. The pedigree chart, as it is called in both human genealogy and domestic animal breeding, is the most basic data collection instrument in both domains. Other paper instruments, including family group sheets and other research logs, are also used, but the pedigree is the exemplar in genealogical record keeping, and forms the basis of the family tree, the medical pedigree, the breeding certificate, the registration certificate, and applications to hereditary patriotic orders. The word "pedigree," 


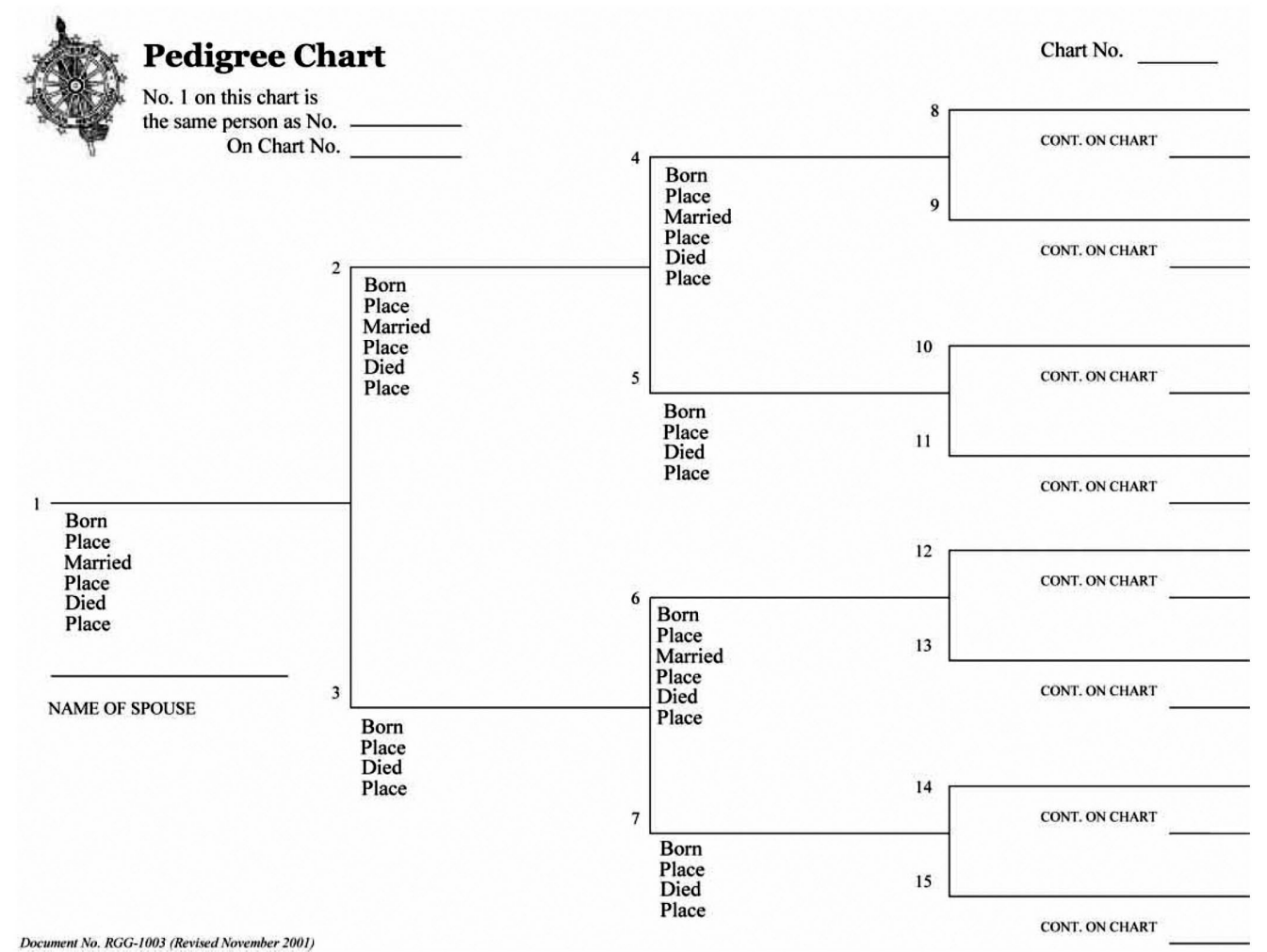

Figure 2. A pedigree chart for documenting descent from a revolutionary patriot. Credit: Daughters of the American Revolution.

with its elite air, descends from the French for "crane's foot," from the lines drawn to indicate succession in early genealogies. Purebred animals have "papers" or documentation of their pedigrees, which presumably is verification not just that the animals' ancestors are noted but that they are also noteworthy. In the human context, people might refer to the pedigrees of aristocrats or "blue bloods," invoking two senses of "good breeding"; that is, coming from known, noteworthy, and racially pure families, and engaging in the genteel behavior appropriate to elite families (see for example, Figure 2).

I use the term pedigree to "emphasize the analogy between human and bovine genealogy" (Ritvo, 1987, p. 60) and to stress the overlap in pedigree practices in human genealogy and reproductive medicine with cattle breeding and improvement programs. Still, in common parlance, ordinary family historians refer less frequently 
to their "pedigrees" than to their "genealogies" or "family trees," unless of course they mean a pedigree chart in particular. And ordinary people, no matter how detailed and long their family record, are unlikely to be referred to as "pedigreed" in this sense, even as having produced such genealogies makes family history known and hence trades rhetorically on the prestige of notable genealogiesthose of people whose long family histories are already known (Wagner, 1972, p. 5) if with greater or lesser devotion to accuracy in every detail (Freeman, 1877). Registered cattle, by definition, are more analogous to these human elites, since their prestigious descent has always been documented (if also sometimes partially fabricated). Those who must resort to researching their family history are most certainly, then, not pedigreed in this sense. On the other hand, the existence of records in which one's family names may be found presupposes elements of privilege related to class, race, sex, property, personhood, and immigration status, and in particular and peculiar ways before the twentieth century.

Though ordinary genealogists do not typically use the word pedigree to refer to their genealogies, they nevertheless are involved in a pastime fraught with pedigreed meanings. In this "ideological retrospective activity" (Du Long, 1986), family historians construct accounts of their ancestors' place in history and, thereby, their own. The establishment of hereditary patriotic orders- organizations that require lineal descent from a heroic ancestor-like the Sons of the American Revolution (1883) and the Daughters of the American Revolution (1890) marked the rise of genealogical research in the United States (Du Long, 1986). John Du Long shows that the assemblages of skills and activities involved in genealogy and supported by genealogical organizations "encourage ideologically loaded images of our ancestors," which in turn "reflect on interpretations of history and patterns of social consensus" (p. 8). Although it is an activity grounded in the past, genealogy has everything to do with life in the present, and increasingly, the future, for these researchers. Unlike genealogies kept to ensure appropriate unions and the legitimate transmission of property, titles, and thrones, present-day family historians do not create documentation for the sake of this kind of inheritance (Hareven, 1978). Still, despite the contemporary purposes for genealogical pursuits, the archival records on which researchers must rely are embedded in 
eighteenth and nineteenth century categories of the human, inextricably bound up with race and class.

The paths cattle have trod with people close behind make them compelling subjects, but recent developments in the use of pedigrees, ARTs, and ICTs compel even more: this constellation of practices in specific configuration resulted in a single purebred Angus bull passing two lethal genetic defects to $10 \%$ of Angus cattle in barely over a decade. The Angus controversy is paralleled in a recent article in The New York Times. Reporting on the emergence of new data about sperm donors since the Donor Sibling Registry (DSR) went online in 2000, the article's headline seems calculated to shock: "One donor, 150 sons and daughters" (Mroz, 2011). The headline concerns about the numbers of children conceived through a single donor quickly slide into anxieties about what counts as family when children have so many genetic half-siblings and the specter of incest should genetic half-siblings meet unknowingly.

As Charis Thompson (2005) argues, the "ontological choreography" of "family building" is "constructed and both nature and society are deployed strategically in this painstaking, highly constrained work of construction" (p. 275). Advocating for enhanced genetic scrutiny of donors, some families produced with the aid of donated gametes worry about the possibility of previously unknown (or unfamiliar) genetic diseases being introduced into their family line (Kramer, 2011). While the donor who contributed to 150 live births appears to be an outlier, with a far greater share of donors having about a dozen genetic progeny, the imaginary of the headline suggests the resemblance between donor insemination and artificial insemination (AI) in industrial livestock production. As pedigree practices take a more explicitly prospective turn in human worlds, the families made through donor gametes are experiencing tensions long felt in cattle breeding.

\section{Of ARTs and EPDs: GAR Precision 1680}

The beautiful bull named GAR Precision 1680 (Figure 3) has many thousands of sons and daughters, and grandsons and daughters, along with his many thousands of siblings, aunts, uncles, and cousins. 


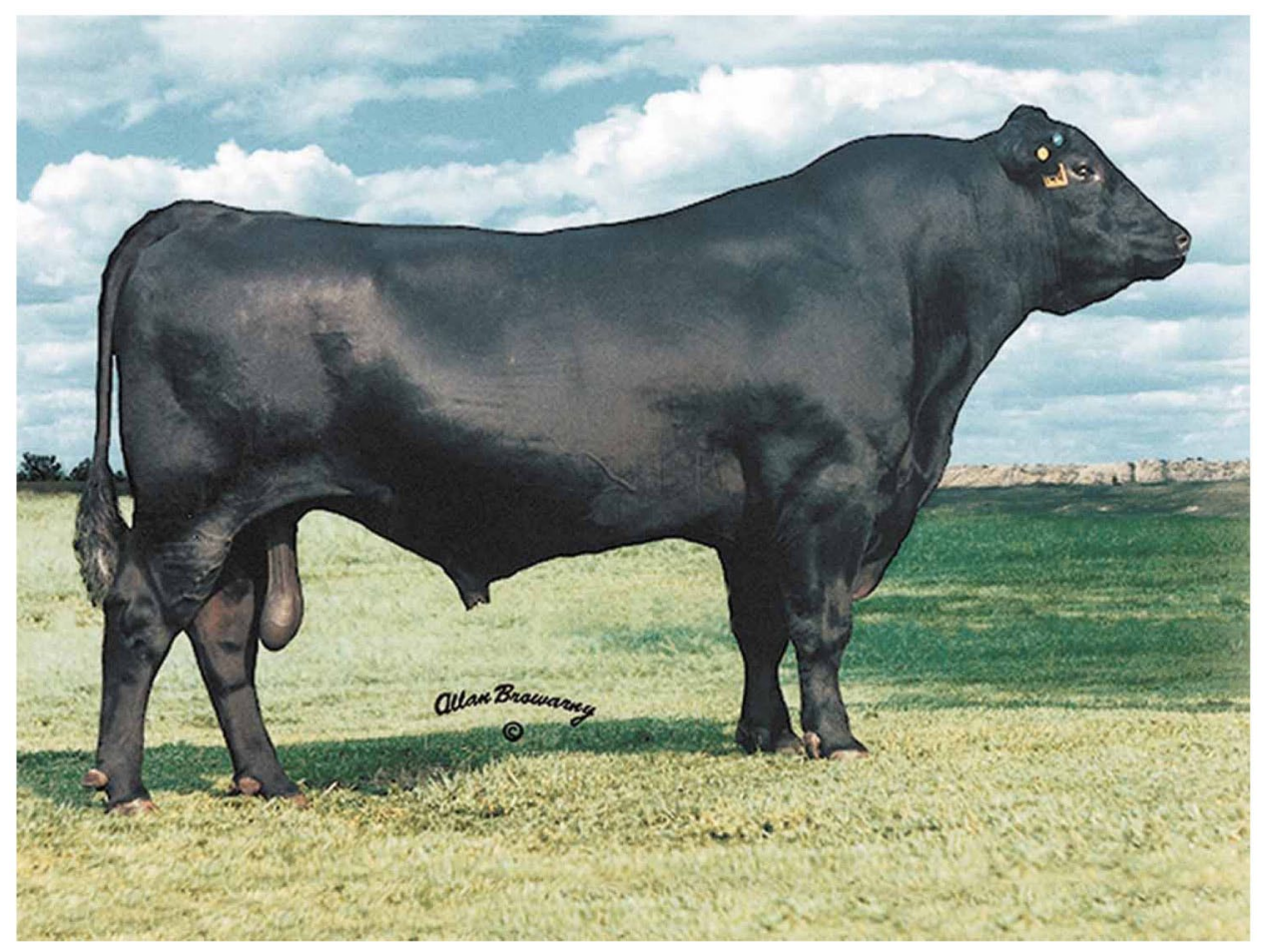

Figure 3. A portrait of GAR Precision 1680, composed to emphasize his assets. Credit: Gardiner Angus Ranch.

Precision 1680 is a tangible link between pedigree practices and the bodies produced through them, brought together in a package of ground beef with a brand on it: Certified Angus ${ }^{\circledR}$. There is a small irony in the fact that a brand is what beef wore when it was still on the hoof; a brand was a marker of property that is now supposed to be a guarantor of quality, or at least trust in the product. Precision 1680 wore the Gardiner Angus Ranch (GAR) brand, along with the number 1680 , burned (or rather, frozen) into the black hide that visually confirmed his eligibility for the Certified Angus Beef ${ }^{\circledR}$ brand.

Precision 1680's pedigree, which can be found online, in the American Angus Association herdbook, lists his sire's line and his dam's line, going back to his great-grandsires and -dams (see Figure 4). The herdbook uses the same kind of pedigree chart that genealogists use, one that branches in two at each generation, and naturalizes the biologistic, heterosexual nuclear family. Appearing directly below Precision 1680 's pedigree on the website is an "expected progeny difference" 


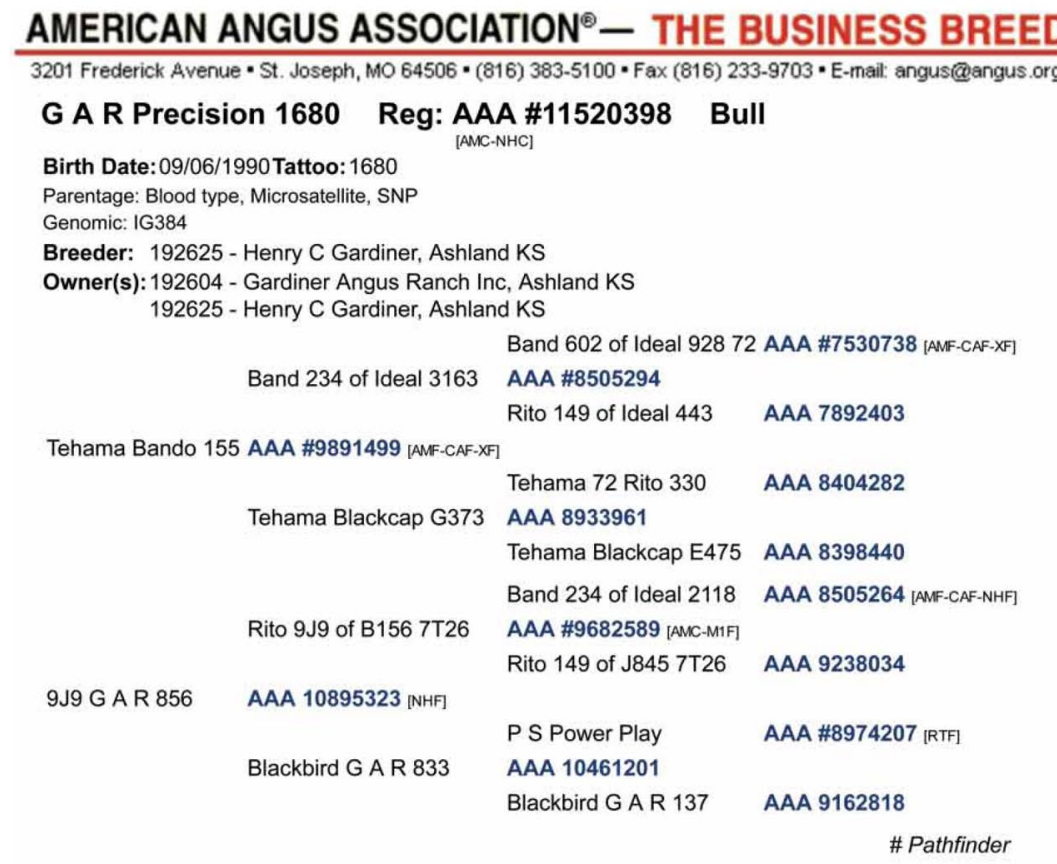

\begin{tabular}{|c|c|c|c|c|c|c|c|c|c|c|c|c|c|c|}
\hline \multicolumn{15}{|c|}{ Production } \\
\hline $\begin{array}{l}\text { CED } \\
\text { ACC }\end{array}$ & $\begin{array}{l}\text { BW } \\
\text { ACC }\end{array}$ & $\begin{array}{l}\text { WW } \\
\text { ACC }\end{array}$ & $\begin{array}{l}\mathrm{YW} \\
\mathrm{ACC}\end{array}$ & $\begin{array}{l}\text { RADG } \\
\text { AcC }\end{array}$ & $\begin{array}{l}\mathrm{YH} \\
\mathrm{Acc}\end{array}$ & $\begin{array}{l}\text { SC } \\
\text { ACC }\end{array}$ & $\begin{array}{l}\text { Doc } \\
\text { ACC }\end{array}$ & $\begin{array}{l}\text { HP } \\
\text { ACC }\end{array}$ & $\begin{array}{l}\text { CEM } \\
\text { ACC }\end{array}$ & $\begin{array}{l}\text { Milk } \\
\text { Acc }\end{array}$ & $\begin{array}{l}\text { MkH } \\
\text { MkD }\end{array}$ & $\begin{array}{l}\text { MW } \\
\text { ACC }\end{array}$ & $\begin{array}{l}\text { MH } \\
\text { ACC }\end{array}$ & $\$ E N$ \\
\hline $\begin{array}{l}+9 \\
.93\end{array}$ & $\begin{array}{c}+1.6 \\
.97\end{array}$ & $\begin{array}{c}+28 \\
.96\end{array}$ & $\begin{array}{c}+67 \\
.95\end{array}$ & $\begin{array}{c}+.13 \\
.69\end{array}$ & $\begin{array}{r}+.1 \\
.96\end{array}$ & $\begin{array}{c}-.94 \\
.96\end{array}$ & $\begin{array}{c}+14 \\
.90\end{array}$ & $\begin{array}{c}+3.8 \\
.80\end{array}$ & $\begin{array}{c}+11 \\
.92\end{array}$ & $\begin{array}{c}+18 \\
.95\end{array}$ & $\begin{array}{l}2112 \\
5505\end{array}$ & $\begin{array}{c}+32 \\
.92\end{array}$ & $\begin{array}{r}+.5 \\
.93\end{array}$ & +10.26 \\
\hline
\end{tabular}

\begin{tabular}{|c|c|c|c|c|c|}
\hline \multicolumn{6}{|c|}{ Carcass } \\
\hline $\begin{array}{l}C W \\
\text { ACC }\end{array}$ & $\begin{array}{l}\text { Marb } \\
\text { Acc }\end{array}$ & $\begin{array}{l}\text { RE } \\
\text { Acc }\end{array}$ & $\begin{array}{l}\text { Fat } \\
\text { Acc }\end{array}$ & $\begin{array}{c}\text { Carc Grp } \\
\text { Carc Pg }\end{array}$ & $\begin{array}{l}\text { Usnd Grp } \\
\text { Usnd Pg }\end{array}$ \\
\hline $\begin{array}{r}+23 \\
.86\end{array}$ & $\begin{array}{c}+.45 \\
.87\end{array}$ & $\begin{array}{c}+.65 \\
.87\end{array}$ & $\begin{array}{c}-.018 \\
.87\end{array}$ & $\begin{array}{c}72 \\
260\end{array}$ & $\begin{array}{l}2240 \\
5427\end{array}$ \\
\hline
\end{tabular}

\begin{tabular}{|c|c|c|c|c|c|}
\hline \multicolumn{6}{|c|}{ \$Values } \\
\hline \$W & \$F & \$G & \$QG & \$YG & \$B \\
\hline+17.45 & +15.55 & +35.09 & +24.00 & +11.09 & +66.00 \\
\hline
\end{tabular}

EPDs are enhanced by genomic results generated by: (2) igenity. (ofizer

192604 09191996; 192625 BO

American Angus Association® 3201 Frederick Ave. St. Joseph, MO 64506

Contact us: phone 816.383.5100 fax 816.233.9703 e-mail

(c) Copyright 2012, All rights reserved. Data Access and Use

Figure 4. GAR Precision 1680's pedigree and EPD. Credit: American Angus Association.

chart, or "EPD" (see Figure 4). An EPD chart is a set of comparisons of the phenotype characteristics of calves a given bull has sired or cow has calved versus all others in the database. 
As one observer put it, Precision 1680 "[bent] the genetic curve" (Ishmael, 2008). His EPD chart demonstrated his prized ability to sire calves who fed out well on the feedlot, resulting in carcasses with a valuably heavy dressed weight. Heifers he sired had an easier than average time delivering their first calves. His body and those of his progeny were assessed with ultrasound while alive, and compiled together with his calves' carcass trait data from the slaughterhouse. On almost every measure cattle growers use, the bull was significantly better than the average purebred Angus. Gardiner Angus Ranch levied every aspect of his reproductive labor to the improvement of Angus stock. Precision 1680 was put into donor service as an artificial insemination (AI) stud; like other AI sires, his semen and embryos from his semen were sold on the internet. Through a host of pedigree practice, including artificial (or assisted) reproductive technologies, Precision 1680 became a very popular sire.

From Fame to Shame: Curly Calf Syndrome

The bull would have been 18 in the autumn of 2008, when rumors that he was responsible for an emerging genetic disease turned to bad news and coagulated into blame. Veterinary scientists Jon Beever and David Steffen, working with the American Angus Association, had collected specimens of some 48 calves, born full term either dead or dying shortly after birth. Their twisted spines had inspired the moniker "Curly Calf Syndrome" as ranchers tried to make sense of what was happening. The Association moved quickly to protect the Angus brand. It issued press releases urging ranchers and breeders to come forward if any suspicious calf mortality had occurred on their ranches. Environmental factors were eliminated and hypotheses generated. Pedigrees were traced and it seemed Precision 1680 was surely to blame.

By late 2008, Beever had located the cause of the disease, now renamed Arthrogryposis Multiplex, in a deletion of about 23,000 base pairs on the first chromosome (Beever, 2009). He then devised a genetic test to be administered by Association-approved genetics firms, and by March 2009 almost 10,000 bulls and cows were found to be carriers of AM; and Precision 1680's maternal grandfather, Rito 9J9 of B156 7T26, was determined to be the actual source of the defective 
gene, though it was largely the popularity of Precision 1680 (and his sons) that distributed the gene through the Angus population.

As the news of Precision 1680's genetic legacy broke, Angus breeders were abuzz. Press releases from ranches that owned the progeny of Rito 9J9 (or Precision 1680) assured buyers with money-back guarantees. Other ranches cancelled their annual sales of sires and replacement heifers. Educational materials explaining Mendelian inheritance were posted on internet bulletin boards in an effort to diffuse anger and confusion. "It created a hysteria I'd never seen before among some seedstock producers,” Mark Gardiner, Precision 1680’s breeder, observed (Ishmael, 2008). The Association published lists of carrier animals. A statement by an Australian veterinary scientist, Laurence Denholm, urging calm deliberation, was widely reproduced in trade magazine articles. According to Denholm:

With this increased semen use, the probability of the bull showing up on both sides of many Angus pedigrees increased to a point where the occurrence, recognition and reporting of the heritable disorders that he carries became inevitable [quoted in Anon (2008), my emphasis].

Denholm continued, calling the situation an "unavoidable byproduct . . . of breeding success." The breeding program that produced Precision 1680 had also produced outstanding calving and carcass traits, helping to make him a popular sire. One implication of this argument is that popular sire syndrome helpfully results in recognition of the disease, which can then be managed. In one sense, this is true: without enough dead calves pointing to particular pedigrees for the development of genetic tests, breeders would have had to conduct expensive and time-consuming progeny tests, in which a bull is bred to 35 of his daughters, in order to rule out or surface defects. Nevertheless, another by-product of this version of "good breeding" was the shrinking of a genetic pool composed of hundreds of thousands of individuals globally.

\section{Stabilizing Facts and Fraying Nerves}

In When Species Meet, Donna Haraway (2008) recounts C. A. Sharp's work to stabilize the existence of Collie Eye Anomaly as a "fact" in 
networks of Australian Shepherd owners, animal scientists, and dog breeders, against the "shoot, shovel, and shut up" instincts of threatened breeders. A large part of Sharp's work was getting breeders to open up their studbooks and share genetic and pedigree information. In Angus worlds, the work to establish and stabilize as "fact" that "Curly Calf Syndrome" was a new genetic disease, Arthrogryposis Multiplex, was considerably faster, partly because the herdbook itself was already a value-added instrument of lively capital (Derry, 2003; Haraway, 2008). Unlike in Aussie purebred worlds, the Angus Association worked quickly to acknowledge and discover the genetic cause of the disease and its source in a sire. This protected not just the Certified Angus ${ }^{\circledR}$ brand, but ultimately also the lucrative trade in gametes and in high performance sires.

Some indications of controversy are evident in statements released by the veterinary science team and the Association (American Angus Association, 2008, 2009a, 2009b). Chiefly, the American Angus Association changed its rule about genetic disease so that cattle that initially tested positive as AM carriers could still be shown and would remain registered. The carrier status was to be noted in the herdbook with the acronym AMC for Arthrogryposis Multiplex Carrier. Tested non-carriers are AM "free," and will have the notation AMF, but unregistered carrier animals born after a grace period-three years for heifers and one year for bulls (marked from the date of the availability of the AM and NH tests)-will not be able to be registered in the herdbook. And the Association put its foot down hard on seedstock producers that sell semen and embryos: the progeny of AI sires who are carriers will be ineligible if they were conceived more than 60 days after the sire's test results were posted, no matter the carrier status of the resulting calf.

This determined pragmatism was an achievement. At the same time as Drs. Beever and Steffen had met with cooperation, and successfully identified a genetic cause and developed a test to contain AM, another problem emerged as a distinct one. Some reports and tissues came from stillborn calves that were assumed to have Curly Calf Syndrome, but that were phenotypically different. At a workshop held at Michigan State University in 2009, Beever recalled that seedstock producers, already rattled from AM, reported back to him one of two species of replies. Some told him, "You don't have a clue. I tested my animals, and [my cow] just lay down and had a dead calf." 
The other response was more helpful: "Well, these [dead calves] are out of tested negative animals. But then, you know what? After looking at the pictures I've seen on the web, these are different. These are not quite the same."

When Beever and Steffen asked artificial insemination companies to contribute samples to another study related to these hydrocephalic fetal calves, purveyors of bull semen pushed back. Rattled after the Angus Association rule changes of 2008, AI producers asked for preliminary results even before a genetic test was validated, accurate, and commercially available. In a strained press release in early April 2009, the Association posted a preliminary list of carriers and noncarrier sires tested for what was named Neuropathic Hydrocephaly. Alert to the potential loss of reputation and valuable semen stocks the list could cause, the Association specifically refused to warranty the results (American Angus Association, 2009b). In the summer of 2010, the Association revised its rules yet again, in the wake of another potentially catastrophic genetic disease, Fawn Calf Syndrome (named, in July 2010, Contractural Arachnodactyly). Contractural Arachnodactyly, estimated to have a maximum frequency of 3-4\% among AI sires, is non-lethal, which presents slightly different challenges to Angus breeders (American Angus Association, 2009a).

\section{Breeds, Brands, and Blame}

Without a doubt, the ability of the American Angus Association and Drs. Steffen and Beever to move quickly here hinged on the bottom line. The production of animals in catteries and puppy mills is a drop in the ocean of animals produced for dairy, eggs, wool, and meat. According to the US Department of Agriculture, more than 34 million head of cattle (plus almost another million calves) went to commercial slaughterhouses in 2008 in the United States alone (National Agricultural Statistics Service, 2009). Angus is the "business breed." These bovines are bred and born for their reproductive labor. Heifers may return to the breeding pool; exemplary bulls go into "natural" or AI service; but the bulk of commercially grown cattle are castrated (if bulls), put out to graze, and finished up on grain on a feedlot before going to the packing plant. 
Thus, Angus growers have a built-in solution to most of their AM and $\mathrm{NH}$ troubles. Dr Beever spelled out these options in a presentation at AAA's annual meeting in November 2008. Commercial cattle growers could do nothing, and just deal with calf loss. Or they could test their entire herds and send every AMC animal to the slaughterhouse. Or, in between these options, growers could test their sires and replace any AM or $\mathrm{NH}$ carriers. In this instance, although some of the cows in the herd may be AM or NH carriers, none of the calves would be affected so long as the sire was not a carrier. Carrier status means an animal is unaffected by $\mathrm{AM}$ and $\mathrm{NH}$, and so is just as valuable for meat as a non-carrier. It would thus be possible to manage these diseases in the herd just by carefully keeping pedigrees. Over time, so long as any replacement heifers were tested before being put into service, cattle growers could eliminate these genes from their herds, while retaining Precision 1680's positive genetic traits. After initial and selective testing, ordinary production ranches could use pedigrees to manage these diseases, and eliminate AMC, NHC, and CAC sires from their herds over time. Since beef profit is born in the slaughterhouse, management of these diseases need not be costly for commercial Angus growers; but for disconsolate owners of Precision 1680 sons and grandsons, who are now known to pass AM and $\mathrm{NH}$ separately, the dollar value of the loss was more substantial.

Other losses may be more difficult to measure. To put the roughly 10,000 tested carriers of AM into perspective, bear in mind that a parent passes a simple Mendelian trait to $50 \%$ of its offspring. Thus, statistically, for each AM carrier calf, there was also an AM free calf born, putting the several generations of registered progeny of Precision 1680, his dam 9J9 GAR 856, and his grandsire Rito 9J9 at more than 20,000 calves. But the actual number is much higher. There were something of the order of 333,000 registered Angus cattle in the US in 2008. According to preliminary research, approximately $8.5 \%$ of $\mathrm{AI}$ studs are carriers of AM, while $10 \%$ are carriers of $\mathrm{NH}$, reflecting Precision 1680's incredible popularity (Beever, 2009). Note that the tested cattle are only those who have been kept in the breeding population. There's no point in testing an animal destined for the slaughterhouse, as most cattle are. Thus, the number of Precision 1680's progeny is many times greater than just those that were tested for AM and $\mathrm{NH}$. 
In the rush to place blame for the Angus breed's woes, the easiest target was line breeding: the practice that amplifies desired traits in a group of animals that thereby become a breed and which led to the success of GAR Precision 1680 in the first place. Line breeding, the nice word for concentrating selected traits in a family line, otherwise known as inbreeding, can contribute to genetic disease in breeds. Just as a pedigree serves to organize discourses of inheritance and quality, it can also provoke anxiety about health and disease.

On cattle discussion boards, participants often believed that inbreeding was the cause of AM in GAR Precision 1680. However, though line breeding feels like the culprit in Precision 1680's unfortunate genetic contribution to the Angus breed, it is not the cause of simple recessive genetic diseases like AM and NH. Random mutations happen, and breeding related animals simply increases the chances that individuals in a population who carry a recessive mutation will have offspring who are homozygous (have two copies of the gene) for that mutation, as Denholm attempted to relate to worried cattle ranchers. But line breeding can lead to polygenic disease, by loading up more problematic genes in a given animal's line. Beever cautions owners of small cow-calf operations that line breeding is a process of ensuring homozygosity for desired traits (so that animals will "breed true"), that in turn causes nearby genes to also become homozygous, leading to a precarious state of affairs.

But the particular issue in Precision 1680's case is popular sire syndrome, in which a few favored males pass their gametes on more frequently than others in a breeding pool. Line breeding established Precision 1680's favorable strengths; AI contributed large numbers of data to increase confidence in the predictive power of Precision 1680's EPD; and popular sire syndrome doomed his line. That is, in terms of simple recessive genetic diseases like $\mathrm{AM}$ and $\mathrm{NH}$, it is not how few ancestors are in Precision 1680's pedigree, but how many pedigrees of other animals he appears in. (According to Beever, a safe threshold for a single gene's frequency in a population is less than $1 \%$.) Because of the sheer number of progeny Precision 1680 has through his service as an AI sire, his EPD scores became highly accurate. Like his gametes, Precision 1680's pedigree- produced EPD travelled as an abstraction of his "genetics," the lucrative heritable traits breeders hope to reproduce. As Lewis Holloway (2005, p. 892) describes 
genetic evaluation practice, the "data are made and studied, particular forms of knowledge of the animal body are gained, but the totality of the animal is lost."

Popular sire syndrome narrows genetic variety by making inbreeding difficult to avoid. Purebred animals share many of the same ancestors, which means a loss of genetic variety. Even without the risk of widespread genetic disease, ranchers with established herds living in differing range environments need bulls whose genetics complement those herds and environments. Seedstock producers selected for the abstracted commercial qualities that are representable in EPDs, which are "distanced from the material body" (Holloway, 2005, p. 894) of the bull and his progeny, including in their environmental contexts.

\section{From Pedigrees to EPDs}

The specific confluence of pedigree practices that led to the extension of GAR Precision 1680 into the sire lines of so many Angus cattle was 100 years in the making. The first Aberdeen Angus cattle were brought from Scotland to Victoria, Kansas in 1873 by George Grant. The American Angus Association was founded in 1883 (as the American Aberdeen Angus Association) to promote the breed. Its first herdbook was printed in 1885, and the technologies and procedures for managing the naturecultural boundaries of the breed increased in complexity as pedigree practices developed. Early American Angus Association registration certificates included the animal's sire, dam, breeder, and owner. Post-war developments at agricultural universities led to efforts to scientifically improve beef cattle. The Angus Association joined this effort, and by 1959 asked members to participate in breed improvement programs by keeping weaning and yearling weight data (Evans, 2001, pp. 140-141).

Over time, the certificate evolved to include a four-generation pedigree, along with birth, weaning, and yearling weight. This was the seed of the carcass evaluation program, which began in 1962. "Estimated breeding value" (EBV) ratios, computed from collected data, began to be printed on registration certificates in 1972 (Evans, 2001, p. 304). Statistical modelling for beef evaluation was developed by 1973 (Chvosta et al., 2001, p. 287). In 1987, the Association began printing 
pedigree certificates with these expected progeny differences (EPDs) printed on them (Evans, 2001, p. 305). Ultrasound evaluation was developed through the 1990s and introduced as a factor on EPDs in 2000 (Evans, 2001, p. 308). Robust EPDs have more predictive power, and this in turn has helped make the development of genetic tests for commercially important traits possible. In 2010, genetic marker testing had developed sufficiently for EPD data to be "genomically enhanced" (Northcutt, 2010).

EPDs are predicated on the oceans of statistics breeders keep as they subject the bodies of their livestock to scrutiny at every phase in their growth. These phenotype data serve as proxies for genetics; "genetic worth is expressed through statistical manipulation of bodily measurements" (Holloway, 2005, p. 886). The database is constantly growing as more data from farms, ranches, and slaughterhouses are entered; thus, EPDs change over time, making new comparisons with higher degrees of accuracy between the 16 million pedigrees and 17 million measurements stored in the herdbook as of 2009. Angus growers are able to compare beeves while they are still alive, using ultrasound to determine what kind of carcass they will produce in the slaughterhouse. EPDs for cattle allow prospective bull and semen buyers to "see 'under the skin'," inside the bodies of the bull's progeny (Holloway, 2005, p. 894).

Angus Patriarchs in the Twenty-First Century

Because of the sheer number of progeny a bull can have, particularly one used in artificial insemination (AI), more data about the heritability of his phenotypic traits are available. ARTs are used often and enthusiastically in breeding worlds. Angus growers can rent a bull for natural service, or buy frozen semen or embryos, or even purchase a pregnant cow whose calf quality is backed by ultrasound examination. Modern AI practice is embedded in pedigrees and EPDs, and relies on several affiliated technologies and knowledges, including cryopreservation, semen extension, and estrus synchronization (Foote, 2002).

Additionally, AI is used in concert with techniques for "flushing" in order to produce embryos in the reproductive tracts of cows, which are then "flushed," microscopically graded, and sorted into 
straws for freezing and later implantation, or "embryo transfer" (ET). The use of AI is now widespread, particularly in the dairy cattle industry where almost all commercial milk cows are impregnated this way, allowing tight control and planning of calving and milk production. But the Angus Association initially resisted the use of the technology when it first became commercially viable in the 1950s, enforcing a range of registration restrictions on calves born as a result of AI (Evans, 2001, pp. 126-127).

The Association and breeders were concerned that AI would allow commercial beef growers to cut pure breeders out of the sire market by breeding their own bulls for use in their herds. AI "was democracy in action. The elite bulls would not be limited to the wealthy" (Foote, 2002, p. 5). Association restrictions proved futile, as members found ways to work around the rules. The breed organization was grappling with these controversies when, in 1968, it was accused of violating anti-trust laws by restricting the use of artificial insemination. The complaint was resolved in 1970, but it was not until 1972 that the use of AI was approved with very few restrictions (Evans, 2001, pp. 127, 193).

Because of the quantity and portability of bull gametes, the sire's relationship to his calves is emphasized over the dam's relationship (M'Charek and Keller, 2008, p. 72). Though "donor cows" can be made to "flush" up to a couple of dozen embryos per attempt, bulls will sire thousands more calves in the same time, and hence have more data for comparison. Due to his profitable ability to pass along these abstracted traits, Precision 1680's gametes travelled the continent and the globe through AI services. The data generated by his calves were fed back into the herdbook, increasing the accuracy of the phenotype predictions on his EPD chart. The widespread use of ARTs has led to robust EPD data and has centered databases (powered by statistical modelling) amongst pedigree practice in livestock breeding worlds, not limited to Angus or cattle.

\section{Conclusions}

In this paper, I develop the concept of "pedigree practices" to encompass the assemblage of processes, technologies, and discourses that 
are organized, explicitly or implicitly, by the pedigree chart. I analyze the story of GAR Precision 1680 as a case study in pedigree practices. This bull serves as an example of the complex relationship between humans and animals in industrialization (Haraway, 2008; Coppin, 2008). The industrialization of animal bodies was advanced by the emergence of data collection and genealogical record keeping, which arose together in the eighteenth century (Ritvo, 1987; Orland, 2004). Prize animals served the rhetorical purpose of reflecting good breeding on their owners (Ritvo, 1987, 1996) at a time when whether "good breeding" was the result of upbringing or parentage was a heated debate in English society (Smithers, 2009). As we learn from Clarke (1998), many techniques now used in human reproductive medicine were developed for use in cattle. The role of cattle as experimental analogues extends the long relationship between human populations and cattle that includes the co-domestication involved in digesting bovine milk proteins (Beja-Pereira et al., 2003; Tishkoff et al., 2007). An animal that can signify prestige and plenty is a companionable rhetorical analogue for working out reproductive anxieties as well.

\section{Pedigree Practices and Animal Bodies}

I raised two questions in the introduction. The first concerns the interplays between and among pedigree practices and animal bodies. As we see in the case of GAR Precision 1680, pedigrees are not just instruments for recording an animal's forebears. In Angus worlds, pedigrees and expected progeny difference charts (EPDs) circulate with discourses about purity, value, and genetics. A known pedigree is a precondition for counting as purebred; it both confers prestige on an animal and serves as a resource through which a prize animal's merit can be explained by virtue of having known ancestors. A pedigree is a tool for the practice of inbreeding, which standardizes animal bodies while at the same time setting purebred animals apart.

The pedigree works as shorthand for "genetics," or the lucrative heritable traits breeders seek to reproduce through line breeding. In the twentieth century, pedigree charts organized new or newly available techniques for enhancing these traits in animals. Data collection as part of breed specific improvement programs enabled statistical evaluation that in turn allowed the abstraction of valuable 
traits into new, indexical and numerical representations called expected progeny differences. The power of these representations also has a numerical indicator in the accuracy score. Accuracy scores increase with the reproductive prowess of an animal, which is itself enhanced with artificial insemination and embryo transfer, creating a feedback loop with EPDs, which in turn encourage the use of a given animal's gametes.

The interplay between these representations of Angus cattle bodies, along with other pedigree practices, and the bodies themselves, is profound, as we learn through the case study of Precision 1680. This is not a cautionary tale about pedigree practices; these genetic diseases simply serve as a marker for how powerful these technologies, processes, and discourses are in combination. The manipulation of animal bodies made possible through the widespread use of pedigree auxiliaries, particularly artificial insemination (AI) and information and computing technologies (ICTs,) including statistical evaluation, had a discernible impact on the Angus breed, as measured by the frequency of two distinct genetic defects, Arthrogryposis Multiplex (AM) and Neuropathic Hydrocephaly (NH). If these two diseases hadn't arisen in such a popular sire, the power of these interacting pedigree practices may have gone unappreciated. A bit of bad luck combined with Precision 1680's favorable traits leveraged, through pedigree practices, $\mathrm{AM}$ and $\mathrm{NH}$ into $10 \%$ of the Angus herd.

Pedigree practices in use today are built on the installed base of earlier technologies and carry the discourses and meanings of those earlier technologies with them (Bowker and Star, 1998). Though the EPD has become the signal abstraction of genetic merit, it does not leave its roots behind. In Precision 1680's case, disagreement over and anxiety about inbreeding, health, disease, and purity was evident, as cattle breeders debated whether good breeding or bad breeding was responsible for the introduction of AM and NH into the Angus breed. At the height of the controversy, the American Angus Association acted quickly to bar the registration of additional animals from registry in the herd book, denying animals with distinguished Angus pedigrees purebred status.

Rule changes in the Angus Association protected the Angus brand, marketing programs like Certified Angus Beef ${ }^{\circledR}(\mathrm{CAB})$, and even the seedstock producers who had invested heavily in GAR Precision 1680's 
sons. Like the Daughters of the American Revolution and other hereditary patriotic orders, $\mathrm{CAB}$, the Angus Association, and seedstock marketers trade on the meanings associated with elite bloodlines. The CAB program draws on "ideologically loaded" (Du Long, 1986) associations with elite livestock breeds, implying that the factors linked with high quality beef are the result of the purity of the breed of the animal. Instead, the quality of $\mathrm{CAB}$ beef is an outcome assured by an inspection and grading process in which only high quality carcasses that happen to have a black hide are eligible for the CAB stamp. In fact, for many commercial growers, Angus cattle are part of a cross breeding plan that relies on heterosis, or hybrid vigor, to produce beef cows that qualify for the $\mathrm{CAB}$ program because they have inherited "Angus influence" in the form of a black hide, which is a dominant trait. The flexible boundary-making for Certified Angus Beef ${ }^{\circledR}$ enables cattle ranchers to earn a premium, increases the demand for Angus sires, and helps to make Angus the "business breed."

The potent case study of GAR Precision 1680 shows how pedigree practices are naturecultural in Haraway's (2008) sense; pedigrees aren't just records of biogenetic relationship, but serve to produce boundaries around breed and family; these boundary-making processes operate in the register of early scientific obsessions with race, miscegenation, hybridity, species boundaries, and taxonomies that centered on reproduction. Naturecultural devices, pedigrees emphasize the analogy between humans and bovines; pedigree practices enact the notions of good breeding embedded in pedigrees. As the story of the horse breeder that opened this paper shows, what counts as "good breeding" is not co-extensive across both domains, but nevertheless involves slippages and overlaps as cattle and other livestock animals have taken the role of rhetorical proxies-not just for human power over animals, but for the meanings of human control over what is arguably most undeniably animal about us-reproduction. Pedigrees carry meanings related to blood, ancestry, history, race, and nation; as Du Long (1986) argues, the practices of producing and maintaining them encourage the development of "ideologically loaded images of our ancestors" (p. 8). This retrospective ideological activity is explicitly prospective in cattle breeding, but it has prospective aspects in humans as well. 


\section{Genealogy as Reproductive Intervention}

This leads to my second, more speculative, question. Given the historical entanglements of human and bovine genealogy and reproductive technologies, how might we think about human reproduction, family history, and genealogy in light of the analytic "pedigree practices" and the case study of Precision 1680? Discourses of biological inheritance, good breeding, and an interest in the rhetorical power of pedigrees co-arose in both domains in the eighteenth century, concomitant with a fascination with races, species, and other biological kinds (Ritvo, 1987, 1996; Smithers, 2009).

Traditional genealogy hasn't been merely about recording biological ancestors. For elite families, pedigrees and lineage were essential to track inheritance of property and titles, as well as to arrange unions that would keep property and titles within family lines. "Breeding" as a noun that means genteel behavior, refined education, and reputable parents, invokes this tradition. Contemporary genealogyarising in the US since the establishment of hereditary patriotic orders after the US centennial-trades on the prestige of elite pedigrees and invokes discourses of heredity superiority, or at the least invests genetic difference between groups and populations with explanatory power for "interpretations of history and patterns of social consensus" (Du Long, 1986, p. 8).

Genealogy is the production of rhetorical ancestors, just as purebreeding is the production of not only material, but also rhetorical, animals, as Ritvo (1987) would have it. Pedigrees don't exist by themselves in human contexts either, but implicitly and sometimes explicitly coordinate a variety of practices, technologies, and discourses much as in livestock pure breeding. They function to choreograph ontologies just as families that use assisted reproductive technologies (ARTs) choreograph ontologies to "make" parents (Thompson, 2005). Increasingly, pedigrees are becoming more than retrospective. The interplay between pedigree practices and bodies in the Angus case is clear. Human bodies are also made through pedigree practices.

Though genealogy has been largely a retrospective activity, the pedigree practices developed in livestock breeding have stakes for prospective constructions of bodies, identity, and family as well. The paper pedigrees of family history have been replaced with software and 
databases; genetic genealogy puts pedigree charts and genetic markers together and allows researchers to identify markers unique to those who are closely related to them. Prospective parents can choose newly affordable over-the-counter medical genetic testing for themselves; preimplantation genetic diagnosis of human embryos is also a readily available option for women using IVF (in vitro fertilization). Aging women of means can extract and cryopreserve their eggs for later use (Gootman, 2012). The use of donor sperm and eggs separates the roles of reproductive partner and life partner, making visible what had been often unconscious or unspoken aspects of partner selection, including physical features, racial and ethnic background, and intellectual and athletic achievement.

On the one hand, tighter genetic screening and the explicit choice of phenotype selection give prospective pedigree practices a eugenic tinge; on the other hand, these families disassemble and reassemble tangled meanings of relatedness as genetic half-siblings navigate friendships, cutting biogenetic family trees apart and rejoining them with naturecultural complexity, as we see in the case of the Donor Sibling Registry (Mroz, 2011). This is only partly new, a techno-cultural permutation of pre-nuclear family arrangements. These families are reckoning personally with the tensions that accompany technologies in their travels between human family making and cattle breeding worlds.

The relationship between humans and nonhuman animals that has given rise to the industrialization of animal bodies is complex. Human bodies are also reshaped and human agency is constrained. While human dominion over animals is undeniable, it isn't total, nor is it without effect on humans (Beja-Pereira et al., 2003; Tishkoff et al., 2007; Haraway, 2008; Coppin, 2008). We see that the technologies we use to control the reproductive lives of cattle and, which in turn, demonstrate our mastery over them, we also turn on ourselves. While pedigree practices represent increased control over animal reproduction and bodies, they have also been instrumental in rendering all animal bodies, including humans, not only more technically but also more discursively available for reproductive interventions.

The story of Precision 1680 is about how a prize bull was created to fill a spot in a prize pedigree, how that pedigree was leveraged and made mobile through reproductive technologies and EPDs, and how 
pedigrees may yet save his doomed line. A beautiful animal, he was genetically lucrative, and his genes travelled the world. He sired so many sons and daughters in part because of his valuable pedigree; data about these sons and daughters increased the value of his pedigree, in turn, making his semen more valuable. A confluence of pedigree practices available at the turn of the twenty-first century that made his "genetics" (in the form of gametes) such a valuable commodity also quickly brought his breed to the precipice of disaster, cost small fortunes to those who owned his sons, and rattled the Angus breeding scene. Each of the practices used by Angus breeders to produce and manage Angus naturecultures speaks to the traffic of these technologies and discourses between human and animal worlds.

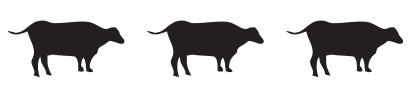

Acknowledgments Thanks to Alexis Shotwell, Peter Murray, Dulcy Perkins, Silkie Perkins, Nora Madden, Donna Haraway, Kim TallBear, Kristin Wilson, Karen De Vries, Astrid Schrader, Simone Chess, Rebecca Schein, Lara Cohen, Susan Potter, Stefanie Caloia, Linda Kalof, Tom Dietz, Larry Busch, John Stone, Shelia Stannard, and Don Laughlin. This paper also benefitted from the feedback of anonymous reviewers and the editors, who gave generously of their time and knowledge. The viewpoints expressed in this paper are my own.

\section{References}

American Angus Association (AAA) (2008) Important Update on the Status of Curly Calf Syndrome (St. Joseph: American Angus Association).

American Angus Association (AAA) (2009a) Fawn Calf Syndrome Update as of December 21, 2009 (St. Joseph: American Angus Association).

American Angus Association (AAA) (2009b) Update: Neuropathic Hydrocephalus (St. Joseph: American Angus Association).

Anon. (2008) American Angus Association reports progress on abnormality, Western Livestock Journal, 26 September, p. 22.

Beever, J. (2009) Update: accessing genetic abnormalities, Cattlemen's Boot Camp, 22 September, Michigan State University, Lansing, MI.

Beja-Pereira, A. et al. (2003) Gene-culture coevolution between cattle milk protein genes and human lactase genes, Nature Genetics, 35(4), pp. 311-313. 
Bowker, G. and Star, S. (1999) Sorting Things Out: Classification and Its Consequences (Cambridge, MA: MIT Press).

Chvosta, J., Rucker, R. and Watts, M. (2001) Transaction costs and cattle marketing: the information content of seller-provided presale data at bull auctions, American Journal of Agricultural Economies, 83(2), pp. 286-301.

Clarke, A. (1998) Disciplining Reproduction: Modernity, American Life Sciences, and the Problems of Sex (Berkeley, CA: University of California Press).

Coppin, D. (2008) Crate and mangle: questions of agency in confinement livestock facilities, in: A. Pickering and K. Guzik (Eds) The Mangle in Practice: Science, Society, and Becoming, pp. 46-66 (Durham, NC: Duke University Press).

Derry, M. (2003) Bred for Perfection: Shorthorn Cattle, Collies, and Arabian Horses since 1800 (Baltimore, MD: Johns Hopkins University Press).

Du Long, J. (1986) Genealogical groups in a changing organizational environment: from lineage to heritage, PhD Dissertation, Wayne State University, Detroit, MI.

Evans, K. (2001) A Historic Angus Journey: The American Angus Association 18832000 (St. Joseph: American Angus Association).

Foote, R. H. (2002) The history of artificial insemination: selected notes and notables, Journal of Animal Science, 8o(2), pp. 1-10.

Freeman, E. A. (1877) Pedigrees and pedigree-makers, The Contemporary Review, pp. 11-41.

Gootman, E. (2012) So eager for grandchildren, they're paying the egg-freezing clinic, The New York Times, May 14, pp. A1, A16.

Haraway, D. (2008) When Species Meet (Minneapolis, MN: University of Minnesota Press).

Hareven, T. (1978) The search for generational memory: tribal rites in industrial society, Daedalus, 107(4), pp. 137-149.

Holloway, L. (2005) Aesthetics, genetics, and evaluating animal bodies: locating and displacing cattle on show and in figures, Environmental Planning D: Society and Space, 23, pp. 883-902.

Ishmael, W. (2008) Dealing with curly calf, Beef Magazine [online]. Available at http://beefmagazine.com/genetics/1201-curly-calf-issue (accessed 20 June 2012).

Kramer, W. (2011) Gamete donation: medical and genetic implications, The $O B /$ GYN Nurse-NP/PA, 3(3), pp. 20-21.

Lee, S. (1993) Racial classifications in the US census: 1890-1990, Ethnic and Racial Studies, 16(1), pp. 75-94.

Lingle, J. (2001) The Breed of Noble Bloods, 2nd ed. (Adelphi, MD: The University of Maryland Foundation).

MacDonald, J. and Sinclair, J. (1882) History of Polled Aberdeen or Angus Cattle: Giving an Account of the Origin, Improvement, and Characteristics of the Breed (Edinburgh: William Blackwood and Sons). 
M'Charek, A. and Keller, G. (2008) Parenthood and kinship in IVF for humans and animals, in: A. Smelik and N. Lykke (Eds) Bits of Life: Feminism at the Intersections of Media, Bioscience, and Technology, pp. 61-78 (Seattle, WA: University of Washington Press).

Mroz, J. (2011) From one sperm donor, 150 children, The New York Times, September 6, pp. D1, D6.

National Agricultural Statistics Service (2009) Livestock Slaughter 2008 Summary (Washington, DC: United States Department of Agriculture).

Northcutt, S. (2010) Pulling it All Together: Genomic-enhanced EPDs (St. Joseph: American Angus Association).

Orland, B. (2004) Turbo-cows: producing a competitive animal in the nineteenth and early twentieth centuries, in: S. Schrepfer and P. Scranton (Eds) Industrializing Organisms: Introducing Evolutionary History, pp. 167-189 (New York: Routledge).

Ritvo, H. (1987) The Animal Estate: The English and Other Creatures in the Victorian Age (Cambridge, MA: Harvard University Press).

Ritvo, H. (1996) Barring the cross: miscegenation and purity in eighteenth- and nineteenth-century Brita, in: D. Fuss (Ed.) Human, All Too Human, pp. 37-57 (New York: Routledge).

Smithers, G. D. (2009) Science, Sexuality, and Race in the United States and Australia, 1780s-189os (New York: Routledge).

Thompson, C. (2005) Making Parents: The Ontological Choreography of Reproductive Technologies (Cambridge, MA: MIT Press).

Tishkoff, S. A. et al. (2007) Convergent adaptation of human lactase persistence in Africa and Europe, Nature, 39(1), pp. 31-40.

Wagner, A. (1972) English Genealogy (London: Oxford University Press). 